\title{
The effects of carabid beetles (Coleoptera: Carabidae) on the arthropod fauna of wheat fields in Chile
}

\author{
R. Carrillo ${ }^{1}$, R. Alarcón ${ }^{2} \&$ M. Neira ${ }^{1}$ \\ 1 Instituto de Producción y Sanidad Vegetal, Universidad Austral de Chile, Casilla 567, Valdivia, Chile; rcarrill@uach. \\ cl. Fax 56-63-221233 \\ 2 Universidad de San Carlos, Mazatenango, Suchitepequez, Guatemala.
}

Received 21-XI-2020. C Corrected 23-IX-2005. Accepted 28-VIII-2006.

\begin{abstract}
The role of carabid beetles in reducing populations of phytophagous insects has been an elusive subject. A field experiment was established on a commercial wheat crop (cv. Otto) with an area of 4.5 ha in Valdivia, Chile, during the spring and summer of 1996-1997. The field had been under a prairie system for two years, before wheat sowing (fertilization and a pesticide had been applied during crop development). Samples were taken at approximately monthly intervals. Carabid beetles were sampled with a grid of pitfall traps and other insects were sampled with a vacuum insect net and soil cores. The genera of the carabids found are of neotropical origin. Exclusion by polythene barriers, together with removal of carabid beetles using traps, was an effective technique for controlling carabid populations in a commercial wheat crop. A reduction in the number of carabid beetles was associated with an increase in the number of springtails and arachnids, and a decrease of agromyzid adults. Phytophagous insects, such as homopterans and lepidopterous larvae, were not affected by carabid exclusion and removal. The action of carabid beetles on the arthropod fauna can be extremely complex, due to its predatory activity at multitrophic levels. Rev. Biol. Trop. 55 (1): 101-111. Epub 2007 March. 31.
\end{abstract}

Key words: Carabids, phytophagous insects, multitrophic interactions, conservative biological control, predator-prey interaction.

The role of carabid beetles in reducing populations of phytophagous insects has been a very elusive subject. According to Lövei and Sunderland (1996), the effectiveness of a natural enemy can be established following four sequential steps: (1) evaluating dynamics and correlating predator and prey density, (2) obtaining evidence of a trophic link between the prey and the predator, (3) manipulating predator numbers and the effect on prey density, and (4) integrating the above information to quantify the effect of predator on prey.

Most studies on carabids and their prey are of the first or second type, fewer investigators have considered steps 3 and 4 . The studies of Wright et al. (1960) and Coaker (1965), showed that the survival of immature stages of the cabbage root fly was negatively related to the number of predatory carabids present on Brassica plots. Edwards et al. (1979), found a negative relationship between numbers of polyphagous predators and aphids in cereals in England. Other studies, however, have failed to find a relationship between the presence of carabids and the populations of phytophagous insects.

The main aim of the present study is to evaluate the effect of carabid beetles (the genera of the carabid fauna found has a neotropical origin) on the wheat arthropod fauna by manipulating beetle abundance. 


\section{MATERIALS AND METHODS}

A field experiment was established on a commercial wheat crop (cv. Otto) with an area of 4.5 ha, at the Universidad Austral de Chile, Experimental Station, Valdivia, Chile (39 $45^{\circ}$ ' S, $73^{\circ} 14^{\prime} \mathrm{W}$ ) during the spring and summer of 1996-1997. The field had been under a praire system for two years, before wheat sowing. Fertilization included chilean nitrate, superphosphate and potassium chloride, at 149-184-96 kg NPK ha-1. The field was treated with glyphosate $1.2 \mathrm{~kg}$ i.a. ha-1, previous to being ploughed and sown to winter wheat in July 1996. The only pesticide applied during the crop development was MCPA at 0.751 i.a. ha-1.

Twelve plots measuring $2 \times 3 \mathrm{~m}$, arranged in a randomized block design of four replicates of three treatments each, were sampled regularly with a vacuum insect net (D-Vac), pitfall and soil cores from September 1996 to January 1997.

The treatments consisted of carabid isolation, carabid isolation and exclusion, and an unisolated area referred to as the control. Carabid isolation was obtained by digging a trench around the plots and erecting a $35 \mathrm{~cm}$ high polythene barrier supported by wooden sticks and buried to a depth of $10 \mathrm{~cm}$. Exclusion was obtained through three pitfall traps per plot, which were kept open throughout the experimental period.

Samples were taken at approximately monthly intervals. Carabid beetles were sampled with a grid of three pitfall traps, e.g. plastic jars $9.5 \mathrm{~cm}$ in diameter, with formaldehyde as preservative. Traps were left in the field for two days, in each trapping period. The entomofauna was vacuum sampled with a vacuum insect net and soil cores. Twenty five $0.092 \mathrm{~m}^{2}$ D-Vac samples and the same number of soil cores $0.20 \times 0.20 \times 0.15 \mathrm{~cm}$ were taken within each plot. Samples were taken to the laboratory in plastic bags. There they were passed through a sieve and then the entomofauna was extracted by hand sorting.

\section{RESULTS}

The number of carabids caught in each treatment (Table 1) (Fig. 1 y 2) shows that significantly $(\mathrm{p} \leq 0.05)$ fewer individuals were

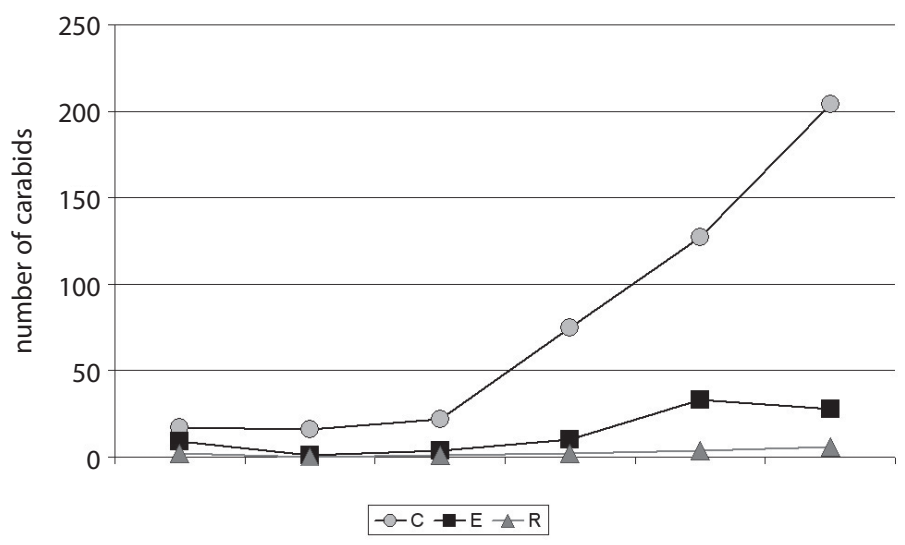

Fig. 1. Total number of carabid beetles caught in each pitfall traps in each of the treatments; Exclusion I-I exclusion and removal $\Delta-\Delta$ and control O-O.

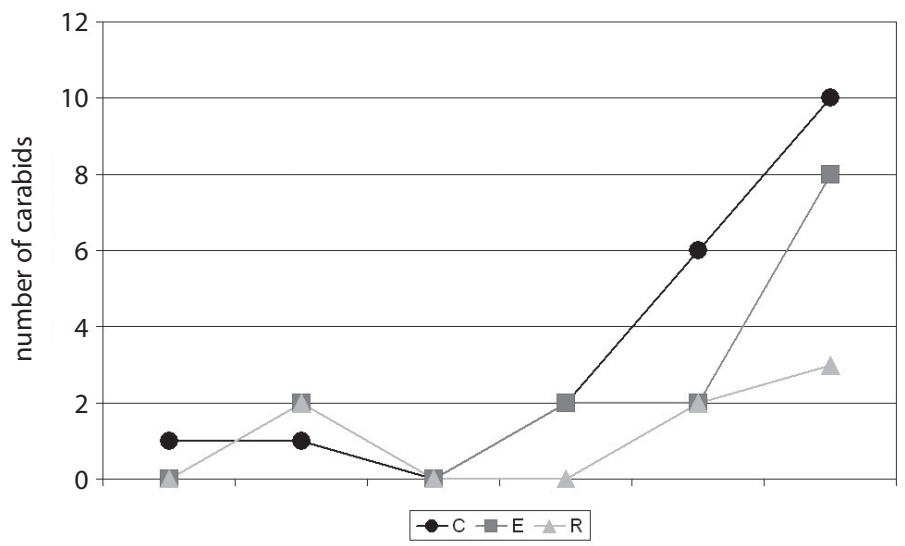

Fig. 2. Number of carabid beetles extracted from soil cores in each of the treatments; Exclusion I-I exclusion and removal $\Delta-\Delta$ and control O-O. 


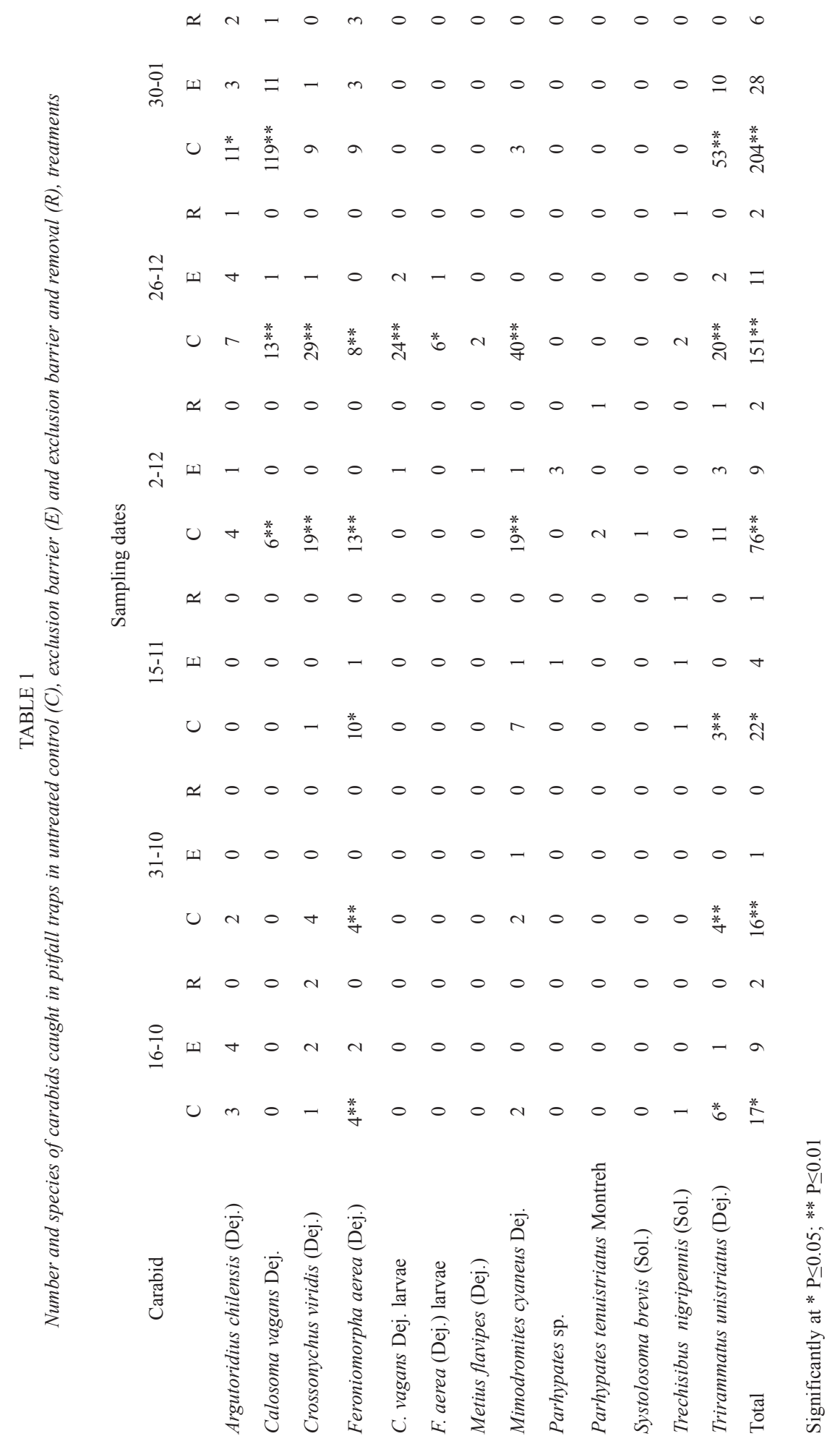


found in the exclusion, and exclusion and removal plots, in relation to the control plots. The results obtained confirmed that polythene exclusion barriers are an adequated method for manipulating carabid density. Considerable variation in the number of carabids trapped throughout the study period was observed. The variation could be related to climate (eg. a steady increase in temperature), during the sampling period. Calosoma vagans Dej., a large beetle, was the most numerous carabid trapped, in spite of being found only during the last three sampling periods.

Pitfall traps also caught, numerous other arthropod groups (Table 2). The most abundant were staphylinid beetles, noctuid larvae and arachnids. Soil cores did not show an effect of the treatments on the non carabid arthropod fauna (Table 3). The effect of polythene barriers on the non carabid arthropod fauna in general was less marked than on the carabid fauna.

Only three groups showed statistically significant differences in the number of individuals collected by D-Vac; they were arachnids, springtails and agromyzids. (Table 4) Springtails showed a marked increase in number, when the carabid population was excluded and removed. Another group that had a similar pattern was the arachnid population. On the other hand the number of agromyzid flies was lower in the exclusion and removal treatment, than in control plots. Groups of important phytophagous insects such as aphids, leafhoppers and noctuid larvae, did not show significant differences in number among the test and control groups.

Because D-Vac sampling is unable to estimate adequately the effect of treatments on the larger insects, such as last noctuid larvae instars, soil cores from the different treatments were hand sorted. Nonetheless, no effect was found on the number of arachnid and noctuid larvae in the different treatments (Table 3).

\section{DISCUSSION}

The efficacy of polythene barriers: the use of polythene barriers as an effective exclusion technique for manipulating the number of carabids to establish their role in regulating prey numbers, has been employed by many researches (Coaker 1965). This study supports previous experimental data, but also shows that this technique is appropiate for removing flying carabids such as $C$. vagans. Results suggest that for this species, dispersal inside fields, after landing, occurs principally by ground movement. The large number of $C$. vagans found in control plots and their absence from exclusion plots suggest that this large species is highly mobile on the ground. It seems likely that many of the individuals caught inside control plots came from adjacent areas, rather than from a large population of this species in the control plots.

The effect of carabids on the arthropod fauna: carabid exclusion did not affect the number of homopterans, even though there are many reports from Europe that polyphagous predators (such as carabids), can restrain some homopterans, (such as cereal aphid populations) at low level. The discrepancy of the results obtained in this study may be explained despite the aphid species being similar in Chile and Europe [Sitobion avenae, $S$. fragarie (Walker) Metopolophium dirhodum (Walker), M. festucae var cerealium (Stroyan) and Rhopalosiphum padi L.] (Carrillo and Zúñiga 1974, Stary 1993), by two main factors. In Chile, cereal aphids are controlled efficiently by introducing aphidiine parasitoids (Norambuena 1981) which keep aphid populations at a very low density. In the current research aphidiine were found in large numbers (Table 4) and were not affected by exclusion barriers. An alternative explanation is that the relationship of carabids with cereal aphids is a new one, because genera of the carabid fauna found has neotropical origin (Reichardt 1977) and cereal aphids are of holartic origin (Szelegiewics 1965, Blackman and Eastop 1985). Introduction of most species of cereal aphids to the neotropical area, occurred only from the mid 1960s onward (Zúñiga 1967, Lara and Zúñiga 1969). However, given the rather unselective feeding behaviour of ground 


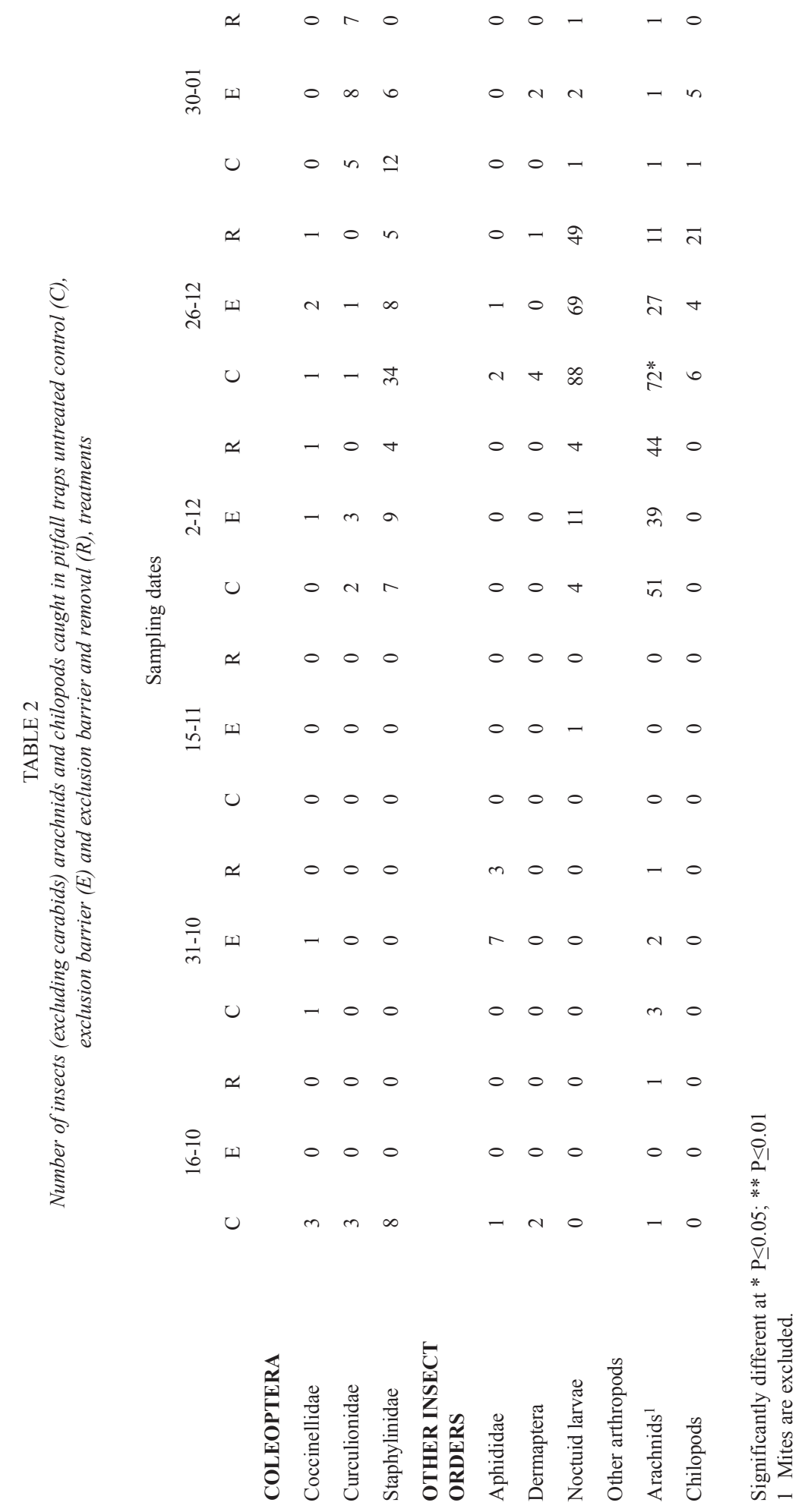




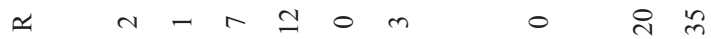

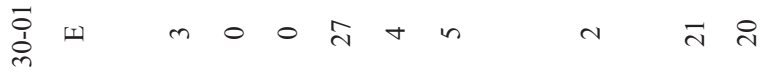

$$
\begin{aligned}
& \text { U } 0 \text { - n a } 6 \text { m - } 2 \text { त } \\
& \simeq \quad \infty-\infty \infty \quad \bar{m} \text { ते }
\end{aligned}
$$

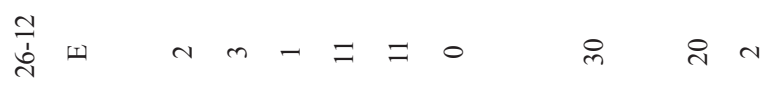

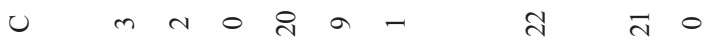

$$
\begin{aligned}
& \simeq \quad 0 N 000000
\end{aligned}
$$

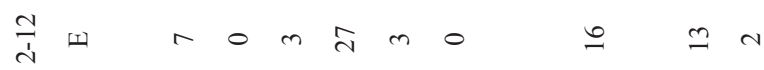

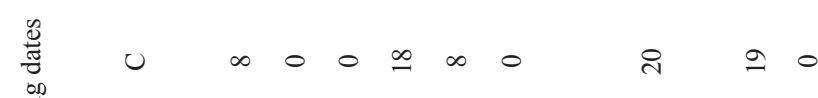

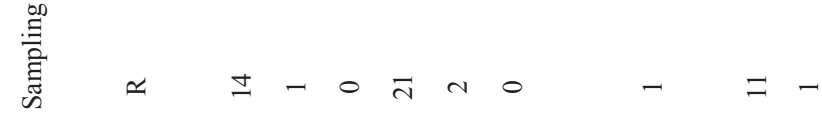

$$
\begin{aligned}
& \text { 光 }
\end{aligned}
$$

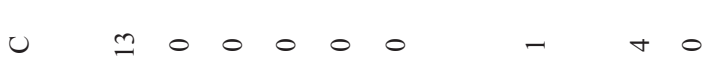

$$
\begin{aligned}
& \text { a n } 0 \text { in } 0 \text { o } 0 \text { o } 00 \\
& \frac{0}{\frac{1}{n}} \text { I I } 0000000 \\
& \text { U } 00-000000 \\
& \simeq 000000000 \\
& \frac{0}{b} \text { II } 000000000 \\
& \text { u } 00 \mathrm{~m} 000000
\end{aligned}
$$

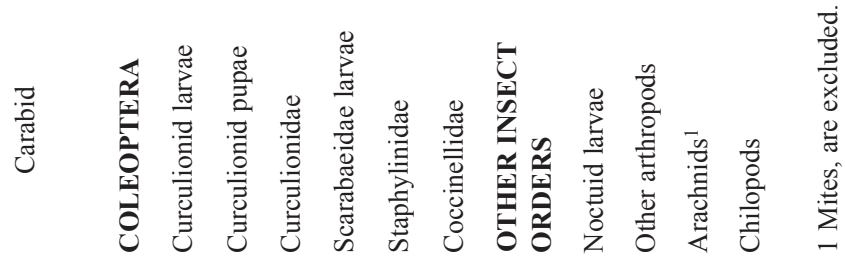




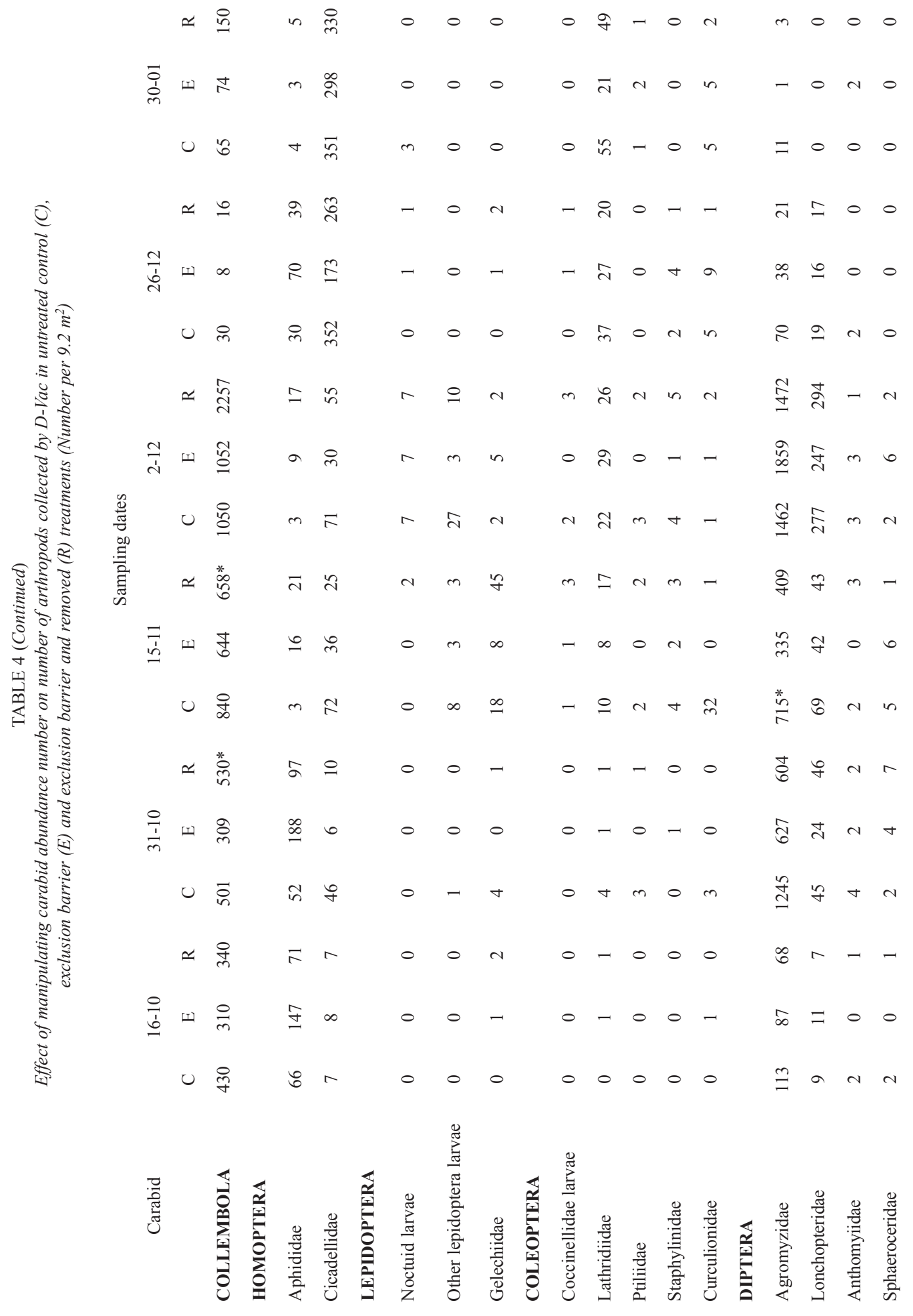




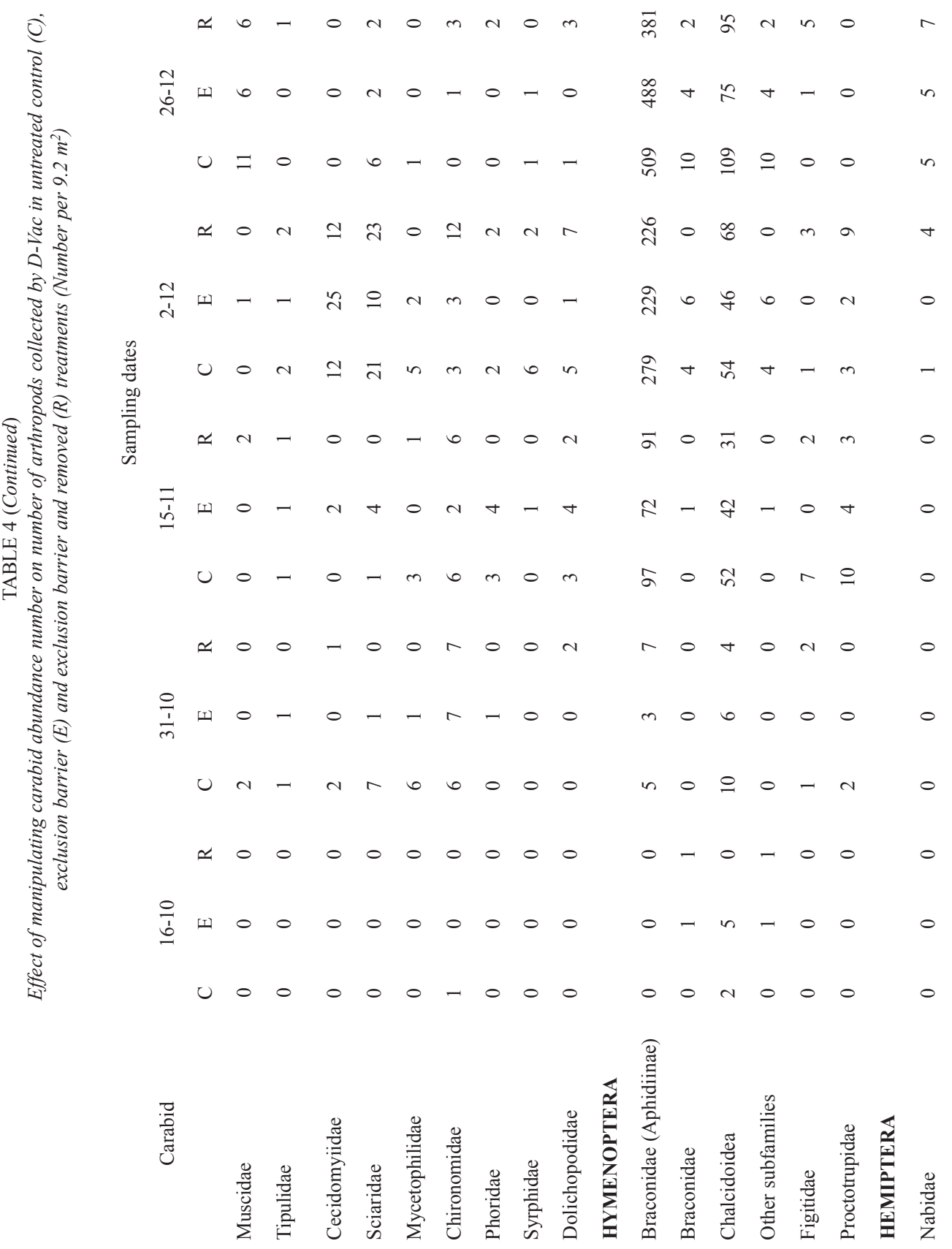




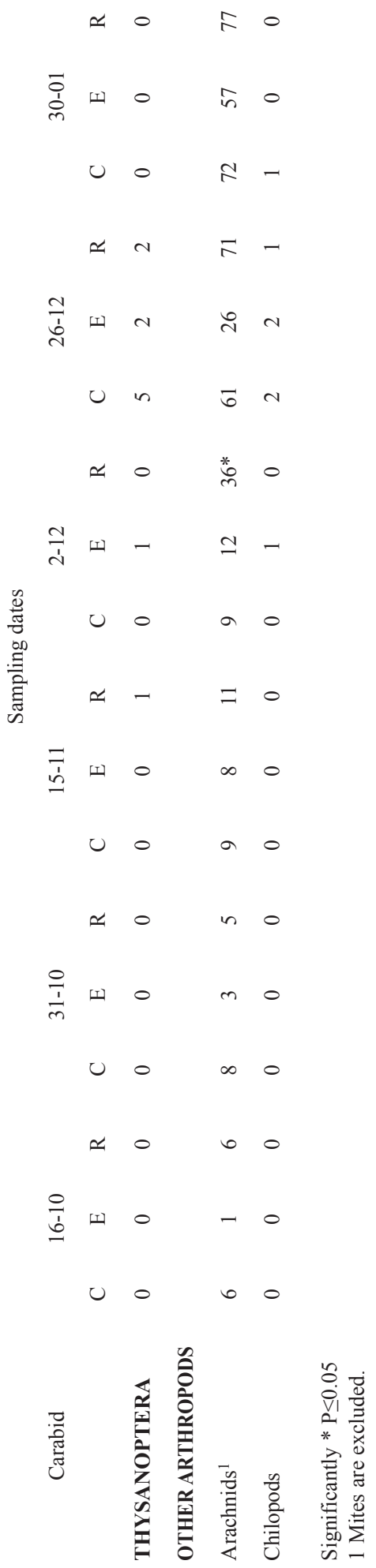

beetles, it is more probable that the first is a more possible explanation.

The number of noctuid larvae did not show statistical differences between exclusion plots and controls, despite the higher presence of $C$. vagans inside the unexcluded crops. Yet, some species of this genus have been used in programmes of biological control (Burgess and Collins 1915). This situation suggest that the methodology of exclusion barriers, may be an unappropiate method for insects able to move actively but unable to surpass polythene barriers, since there is a constant replenishment of new insects (larvae) from the surrounding area in control plots, a situation that does not occur in exclusion plots. In addition, operating pitfall traps continuously in exclusion and removal plots, can catch a large number of noctuid larvae, such as occured in this experiment (Table 2) and may be the mechanism responsible for supress its numbers; therefore, the lack of an effective regulation of noctuid larvae by carabids may be an artefact of the methodology employed.

The large increase in the number of springtails in the exclusion and removal treatment in relation to the other two treatments, could have occured through two different processes, acting independently or in a complementary way. The removal of carabids may have reduced the predatory pressure on springtails, allowing an increase in their number, since some species of carabids are important predators of these insects. On the other hand, because carabids are polyphagous predators, they could supress other springtail antagonists, such as arachnids (Dinter 1998, Sunderland et al. 1994) and through this mechanism, increase the number of springtails. This may also be the case for agromyzid adults: An increase in the number of arachnids during one of the sampling dates in plots with exclusion and removal may be related to the predatory action of carabids on arachnids (mites excluded). The study shows that the effect of polyphagous opportunistic predators, such as carabid beetles, on the invertebrate fauna of ecosystems can be extremely complex. Due to their wide range of prey, they can interact with plant-invertebrate food webs, 
feeding at several trophic levels simultaneously. There are many cases in the literature on the effect of insectivorous birds feeding at different trophic levels, which can increase pest populations, when the effect predator suppresion is greater than the direct mortality caused on the pest (cascade effect) (Tscharntke 1977). Invertebrate predators preying at different trophic levels have been less studied, but there are also examples of how a predator can interfere with other predators through intraguild predation and then indirectly cause an increase of the prey (Press et al. 1974, Rosenhein et al.1995). In summary the number and diversity of polyphagous predators can play an important role in affecting the population stability of phytophagous insects.

\section{ACKNOWLEDGMENTS}

This work was supported by Fondo Nacional de Ciencias y Tecnología de Chile (FONDECYT No 1940886).

\section{RESUMEN}

El uso de barreras de polietileno, conjuntamente con la remoción de carábidos usando trampas de caída, demostró ser una técnica efectiva en la manipulación de las poblaciones de estos insectos en un trigal comercial. La reducción en el número de carábidos se asoció con un incremento en el número de colémbolos y arácnidos, y con una disminución en el número de agromízidos. Las especies fitófagas del orden Hemiptera y las larvas de nóctuidos no fueron afectadas en su cantidad por la exclusión y remoción de los carábidos. La acción de los carábidos sobre la fauna de artrópodos puede ser extremadamente compleja, debido a su actividad depredadora a distintos niveles en la cadena trófica.

Palabras clave: Carábidos, insectos fitófagos, interacciones multitróficas, control biológico conservativo, interacción depredador-presa.

\section{REFERENCES}

Blackman, R. \& E. Eastop. 1985. Aphids on the world's crops. An Identification Guide. John Wiley, Chichester, England. 466 p.

Burgess, A.F. \& C.W. Collins. 1915. The Calosoma beetle (Calosoma sycophanta): in New England. US Dept. Agric. Bull. 251. 40 p.

Carrillo, R. \& E. Zúñiga. 1974. Key to identify aphids (Homoptera: Aphididae) infesting cereal crops in Chile. Agro Sur 2: 86-87.

Coaker, T.H. 1965. Further experiments on the effect of beetle predators on the numbers of the cabbage root fly, Erioischia brassicae (Bouché), attacking brassica crops. Ann. Appl. Biol. 56: 7-20.

Dinter, A. 1998. Intraguild predation between erigonid spiders, lacewing larvae and carabids. J. Appl. Entomol. 122: 163-167.

Edwards, C.A., K.D. Sunderland \& K.S. George. 1979. Studies of polyphagous predators of cereal aphids J. Appl. Ecol. 16: 811-823.

Lara de Z, S. \& E. Zúñiga. 1969. Metopolophium dirhodum (Walker) (Homoptera: Aphididae) New record for Chile, important wheat pest. Simiente 39: 34-36.

Lövei, G. \& K. Sunderland. 1996. Ecology and behaviour of ground beetles (Coleoptera: Carabidae). Annu. Rev. Entomol. 41: 231-256.

Norambuena, H. 1981. Introduction and establishment of parasitoids (Hymenoptera: Aphidiidae) for biological control of Metopolophium dirhrodum (Walker) and Sitobion avenae (Fabricius) (Homoptera: Aphididae) in southern Chile. Agr. Téc. 41: 95-102.

Press, J., R. Flaherty \& R. Arbogast. 1974. Interactions among Plodia interpunctella, Bracon hebetor and Xylocoris flavipes Environ. Entomol. 3: 183-184.

Reichardt, H. 1977. A synopsis of the genera of Neotropical Carabidae (Insecta: Coleoptera). Quaest. Entomol. 13: 346-493.

Rosenheim, J.A., H.A. Kaya, L.E. Ehler, J.J. Marois \& B.A. Jaffee. 1995. Intraguild predation among biological control agents: Theory and evidence. Biol. Control 5: 303-335. 
Stary, P. 1993. The fate of released parasitoids (Hymenoptera: Braconidae: Aphidiidae) for biological control of aphids in Chile. Bull. Entomol. Res. 83: 633-639.

Sunderland, K.D., S.J. Ellis, A. Weiss, C.J. Topping \& S.I. Long. 1994. The effects of polyphagous predators on spiders and mites in cereal fields. ProoceedingsBrighton Crop Protection Conference, Pests and Diseases, British Crop Protection Council, Brighton, England. p. 1151-1156.

Szelegiewicz, H. 1965. Studies on the Tribe Pterocommatini Mordv. (Homoptera: Aphididae). Part I. Phylogeny and generic classification. Ann. Zool. 23: 251-301.
Tscharntke, T. 1997. Vertebrate effects on plant-invertebrate food webs, p. 277-297. In A.C. Gange \& V.K. Brown (eds.). Multitrophic interactions in terrestrial systems $36^{\text {th }}$ Symposium of the British Ecological Society, London, England.

Wright, D.W., R.D. Hughes \& J. Worrel. 1960. The number of certain predators on the numbers of cabbage root fly (Erioischia brassicae (Bouché)) and on the subsequent damage caused by the pest. Ann. Appl. Biol. 48: 756-763.

Zúñiga, E. 1967. Preliminary list of aphids that infest crops in Chile, their hosts and natural enemies. Agric. Tec. 27: 165-177. 
